\title{
Evaluation of Neem Oil in Combination with Wetting Agent as Larvicide against Spodoptera frugiperda (Noctuidae: Lepidoptera)
}

\author{
Anita Singh ${ }^{1 *}$, Rajas Warke ${ }^{2}$ Kavita Khadke ${ }^{3}$, Pallavi Waykole ${ }^{4}$ \\ ${ }^{1}$ Entomologist, Department of Agriculture, Warkem Biotech Pvt. Ltd., Mumbai, India \\ ${ }^{2}$ Technical Director, Department of Agriculture, Warkem Biotech Pvt. Ltd., Mumbai, India \\ ${ }^{3}$ Technical Director, Department of Agriculture, Warkem Biotech Pvt. Ltd., Mumbai, India \\ ${ }^{4}$ Department of Agriculture, Warkem Biotech Pvt. Ltd., Mumbai, India
}

*Address for Correspondence: Dr. Anita Singh, Entomologist, Department of Agriculture, Warkem Biotech Pvt. Ltd., L.B.S. Marg, Mumbai, India

E-mail: anita.singh282@gmail.com

Received: 31 Jul 2019/ Revised: 23 Sep 2019/ Accepted: 28 Dec 2019

\begin{abstract}
Background: Fall armyworm (FAW) Spodoptera frugiperda (Noctuidae: Lepidoptera) is native of America is now considered as invading pest in India. It causes damage to maize, wheat, rice, sugarcane, etc. The aim of this study was evaluation of neem oil in combination with wetting agent (SuperStiker) as larvicide against Spodoptera frugiperda (Noctuidae: Lepidoptera).

Methods: The present study was conducted to evaluate the larvicidal effect of neem oil (WA391: Nim Q) with combination of wetting agents (WA306: SuperStiker). Topical application of different combination of Neem Oil and SuperStiker along with control was given to selected days (2, 4, 6 and 12 days) larvae.

Results: The result revealed that the highest mortality percentage was recorded with the combination of $2 \mathrm{ml} \mathrm{Neem} \mathrm{oil}+5 \mathrm{ml}$ of SuperStiker in all selected larvae after 24 hours of exposure.

Conclusion: Hence use of $\mathrm{Nim} \mathrm{Q}$ and SuperStiker in combination was most effective for control FAW population. Therefore, this kind of study will motivate the use of more ecofriendly, less toxic control measuresto decrease the FAW population in agriculture field.
\end{abstract}

Key-words: Larvicidal, Mortality, Nim Q, Spodoptera frugiperda, SuperStiker

\section{INTRODUCTION}

Spodoptera frugiperda (Noctuidae: Lepidoptera) is native of tropical and subtropical region of America commonly known as fall armyworm ${ }^{[1,2]}$. It sprayed to African as invasive alien insect pest species from 2016 onward ${ }^{[3]}$. Sangomla et al. ${ }^{[4]}$ reported that the FAW invaded Asia through Yemen and India, and then spread to Bangladesh, Myanmar, Nepal and China. The first record of the FAW attack is reported from Karnataka and further it sprayed to 20 states in India on Maize ${ }^{[5]}$.

\section{How to cite this article}

Singh A, Warke R, Khadke K, Waykole P. Evaluation of Neem Oil in Combination with Wetting Agent as Larvicide against Spodoptera frugiperda (Noctuidae: Lepidoptera). SSR Inst. Int. J. Life Sci., 2020; 6(1): 2462-2468.

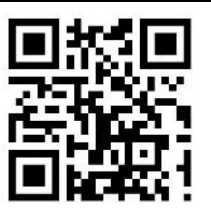

Ganiger et al. ${ }^{[6]}$ reported the occurrence of FAW in maize field of Karnataka. The FAW on the sugarcane reported from the belts of $M / s$ Sakthi Sugars Ltd., Modakurichi, Erode district, and M/s E.I.D. Parry (India) Ltd., Pugalur, Karur district, Tamil Nadu, India in November $2018{ }^{[7]}$. Sisodiya et al. ${ }^{[8]}$ reported FAW from sweet corn field in the Anklav village of Anand district Gujarat. Further Chormule et al. ${ }^{[9]}$ reported FAW on sugarcane, maize, sorghum and sweet corn in different district of Maharashtra, India.

The presence of high host range i.e. 350 host plants, including maize, rice, sorghum, sugarcane and wheat; survival capacity under harsh conditions of hiding and migrating to different places and the ability of adult FAW female to travel long distance (around $100 \mathrm{~km}$ ), which make FAW major concern agriculture pests ${ }^{[4]}$. To control this invasive pest, many synthetic insecticides have been widely used to slow its spread and minimize the damage. 
This injudicious and indiscriminate use of wide range insecticides has led to the development of resistance ${ }^{[10]}$, so best alternative to these insecticides are the use of botanicals for control of fall armyworm. There are many plants which are having insecticidal properties and used traditionally by farmers ${ }^{[11-14]}$. Even many botanicals like Myrciaria cauliflora, Argemone ochroleuca, Azadirachta indica, etc. are showing the toxic effect against FAW ${ }^{[15-}$ 17]. Out of many botanicals, neem is considered for present study due to its easy availability for isolation of oil. Neem oil, extracted from the neem tree, $A$. indica (family: Meliaceae) seeds having phytochemicals ${ }^{[18]}$. The major constituent of neem is azadirachtin ${ }^{[19]}$. It acts as antifeedant, repellent, growth inhibitor or growth regulator ${ }^{[20]}$. The use of neem is safe for workers, with no handling risks, can be used throughout the entire crop production cycle, it is also low toxic to non-target organisms makes it as most favorites among researchers ${ }^{[21,22]}$. But only very small part of the total amount of pesticides applied for weed and pest control actually reaches the sites of action, due to larger proportion being lost via spray drift, off-target deposition, run-off and photo degradation ${ }^{[23]}$. So, the use of a wetting agent or surfactant will minimize the loss of pesticides. Hence the present study was conducted to evaluate the larvicidal effect of neem oil in combination of wetting agent on selected days of fall army worm larvae.

\section{MATERIALS AND METHODS}

The present study was conducted in Entomology laboratory, Warkem Biotech Pvt. Ltd., Mumbai, India duration of 2018 to 2019.

Mass rearing of fall army worm- The collected pupae from the unsprayed maize field in Entomology laboratory, Warkem Biotech Pvt. Ltd. Mumbai. These collected pupae were kept in a container for molting into adults. The newly molted adults (male and female) were kept in the container $(30 \mathrm{~cm} \times 30 \mathrm{~cm} \times 50 \mathrm{~cm})$ having freshly cut leaves of maize and $20 \%$ honey dipped cotton in petri-plate for mating. The gravid females were laid egg patches on freshly cut leaves of maize. These larvae hatched and to avoid cannibalism, newly hatched larvae were separated and kept in individual vials. The further rearing and breeding was done at $24 \pm 1^{\circ} \mathrm{C}, 70 \% \mathrm{RH}$, and $14 \mathrm{~L}$ : $10 \mathrm{D}$ photoperiod. The proper, timely cleaning and food was provided at regular interval. Further 2, 4, 6 and 12 days old larvae stages were collected for conducting larvicidal study. Finally, the five replications were kept (20 larvae for each different stage).

Treatments- Two hours pre-starve selected days fall army worm larvae were exposed to following treatment along with the control. Topical application was used for recording the efficiency of product at $24^{\circ} \mathrm{C} \pm 2^{\circ} \mathrm{C}$ and $\mathrm{RH}$ 70-75 \% (14 L: $10 \mathrm{D}$ photoperiod) along with control. Total five replicates were kept for all treatment (Table 1).

Table 1: Details of different treatment used in the experiment

\begin{tabular}{|c|c|}
\hline Different Treatment & Treatment Details \\
\hline T1 & $1 \mathrm{ml}$ SuperStiker $+0.5 \mathrm{ml} \mathrm{Nim-Q}$ \\
\hline $\mathrm{T} 2$ & $2 \mathrm{ml}$ SuperStiker $+0.5 \mathrm{ml} \mathrm{Nim}-\mathrm{Q}$ \\
\hline T3 & $3 \mathrm{ml}$ SuperStiker $+0.5 \mathrm{ml} \mathrm{Nim}-\mathrm{Q}$ \\
\hline T4 & $4 \mathrm{ml}$ SuperStiker $+0.5 \mathrm{ml} \mathrm{Nim}-\mathrm{Q}$ \\
\hline T5 & $5 \mathrm{ml}$ SuperStiker $+0.5 \mathrm{ml} \mathrm{Nim}-\mathrm{Q}$ \\
\hline T6 & $0.5 \mathrm{ml} \mathrm{Nim-Q}$ \\
\hline $\mathrm{T7}$ & $1 \mathrm{ml}$ SuperStiker $+1.0 \mathrm{ml} \mathrm{Nim-Q}$ \\
\hline T8 & $2 \mathrm{ml}$ SuperStiker $+1.0 \mathrm{ml} \mathrm{Nim-Q}$ \\
\hline T9 & $3 \mathrm{ml}$ SuperStiker $+1.0 \mathrm{ml} \mathrm{Nim-Q}$ \\
\hline T10 & $4 \mathrm{ml}$ SuperStiker $+1.0 \mathrm{ml} \mathrm{Nim}-\mathrm{Q}$ \\
\hline T11 & $5 \mathrm{ml}$ SuperStiker $+1.0 \mathrm{ml} \mathrm{Nim-Q}$ \\
\hline $\mathrm{T} 12$ & $1.0 \mathrm{ml} \mathrm{Nim}-\mathrm{Q}$ \\
\hline T13 & $1 \mathrm{ml}$ SuperStiker $+1.5 \mathrm{ml} \mathrm{Nim-Q}$ \\
\hline T14 & $2 \mathrm{ml}$ SuperStiker $+1.5 \mathrm{ml} \mathrm{Nim-Q}$ \\
\hline T15 & $3 \mathrm{ml}$ SuperStiker $+1.5 \mathrm{ml} \mathrm{Nim}-\mathrm{O}$ \\
\hline T16 & $4 \mathrm{ml}$ SuperStiker $+1.5 \mathrm{ml} \mathrm{Nim-Q}$ \\
\hline T17 & $5 \mathrm{ml}$ SuperStiker $+1.5 \mathrm{ml} \mathrm{Nim}-\mathrm{Q}$ \\
\hline T18 & $1.5 \mathrm{ml} \mathrm{Nim}-\mathrm{Q}$ \\
\hline T19 & $1 \mathrm{ml}$ SuperStiker $+2.0 \mathrm{ml} \mathrm{Nim}-\mathrm{O}$ \\
\hline $\mathrm{T} 20$ & $2 \mathrm{ml}$ SuperStiker $+2.0 \mathrm{ml} \mathrm{Nim-Q}$ \\
\hline $\mathrm{T} 21$ & $3 \mathrm{ml}$ SuperStiker $+2.0 \mathrm{ml} \mathrm{Nim}-\mathrm{O}$ \\
\hline $\mathrm{T} 22$ & $4 \mathrm{ml}$ SuperStiker $+2.0 \mathrm{ml} \mathrm{Nim-Q}$ \\
\hline $\mathrm{T} 23$ & $5 \mathrm{ml}$ SuperStiker $+2.0 \mathrm{ml} \mathrm{Nim}-\mathrm{O}$ \\
\hline $\mathrm{T} 24$ & $2.0 \mathrm{ml} \mathrm{Nim}-\mathrm{Q}$ \\
\hline Control & Water Spray \\
\hline
\end{tabular}

Statistical Analysis- After $24 \mathrm{~h}$ of the exposure period, the number of dead larvae was recorded from each replicates at all the dosage and the percentage of larval mortality was calculated using the Abbott's formula ${ }^{[24]}$.

$$
\text { Mortality }(\%)=\frac{(X-Y)}{X} \times 100
$$




\section{RESULTS}

The present investigation revealed that the maximum i.e. $100 \%$ mortality was recorded when two days old larvae of the fall army worm exposed to 1.5 and $2.0 \mathrm{ml}$ of neem oil (Nim Q) in combination with all five different dosages of SuperStiker $(1.0,2.0,3.0,4.0$ and $5.0 \mathrm{ml})$. With $1.0 \mathrm{ml}$ of $\operatorname{Nim} Q$ the absolute mortality was observed with 2.0, 3.0, 4.0 and $5.0 \mathrm{ml}$ of SuperStiker, whereas the minimum mortality (71\%) was recorded when larvae get exposed to $0.5 \mathrm{ml}$ neem oil and $1.0 \mathrm{ml}$ SuperStiker. The result also revealed that Nim Q without SuperStiker was shows low mortality percentage compared to all selected dosage of Nim $Q$ and SuperStiker combination (Table 2).

Maximum 100\% mortality were recorded in 4-day old larvae of the fall army worm, when larvae get exposed to $2.0 \mathrm{ml}$ neem oil ( $\mathrm{Nim} \mathrm{Q}$ ) in combination of 2.0, 3.0, 4.0, and $5.0 \mathrm{ml}$ SuperStiker. When larvae exposed to $1.5 \mathrm{ml}$ of neem oil in combination of $3.0,4.0$, and $5.0 \mathrm{ml}$ SuperStiker the absolute mortality was recorded, whereas with $1.0 \mathrm{ml}$ neem oil the $100 \%$ mortality was recorded in combination of 4.0 and $5.0 \mathrm{ml}$ of SuperStiker. The minimum mortality of second instar of the fall army worm was recorded as $68 \%$ in combination of $0.5 \mathrm{ml}$ neem oil and $1.0 \mathrm{ml}$ SuperStiker. The result also revealed that Nim Q without SuperStiker was showing low mortality percentage compared to all selected dosage of Nim $Q$ and SuperStiker combination (Table 2).

In 6-day old larvae the maximum i.e. $100 \%$ mortality was recorded in $1.5 \mathrm{ml}$ and $2 \mathrm{ml}$ neem oil with a combination of 3,4 , and $5 \mathrm{ml}$ SuperStiker. When larvae exposed to 1.0 $\mathrm{ml}$ neem oil the absolute mortality was recorded in 4 and $5 \mathrm{ml}$ of SuperStiker, whereas the minimum mortality was recorded at $60 \%$ in combination of $0.5 \mathrm{ml}$ neem oil and $1.0 \mathrm{ml}$ SuperStiker. The result also revealed that $\mathrm{Nim} \mathrm{Q}$ without SuperStiker was showing low mortality percentage compared to all selected dosage of $\mathrm{Nim} \mathrm{Q}$ and SuperStiker combination (Table 2).

When 12-day old larva stage exposed to $\mathrm{Nim} Q$ dosage $(1.5 \mathrm{ml}$ and $2 \mathrm{ml})$ in combination with $5 \mathrm{ml}$ of SuperStiker causes maximum $96 \%$ mortality after 24 hours of exposure of 12-day old larvae. The minimum mortality was recorded as $37 \%$ with $0.5 \mathrm{ml} \mathrm{Nim} \mathrm{Q}$ and $1.0 \mathrm{ml}$ SuperStiker in 12-day old larvae when compared to control. The result also revealed that $\mathrm{Nim} Q$ without SuperStiker was showing low mortality percentage compared to all selected dosage of $\mathrm{Nim} Q$ and SuperStiker combination (Table 2).

Table 2: Mean percentage ( \pm SEM) of cumulative Mortality of selected days FAW larvae at $24 \mathrm{~h}$ after application of different treatment in a laboratory test

\begin{tabular}{ccccc}
\hline \multirow{2}{*}{$\begin{array}{c}\text { Treatment Details per } \\
\text { litre of water }\end{array}$} & \multicolumn{4}{c}{ Selected days, larval stages use for treatments } \\
\cline { 2 - 5 } T1 & $71.0 \pm 1.00$ & 4 days & $\mathbf{6}$ days & 12 days \\
\hline T2 & $77.0 \pm 1.22$ & $75.0 \pm 1.58$ & $62.0 \pm 1.22$ & $37.0 \pm 2.54$ \\
T3 & $80.0 \pm 2.73$ & $70.0 \pm 2.73$ & $46.0 \pm 2.44$ \\
T4 & $93.0 \pm 1.2$ & $91.0 \pm 1.8$ & $78.0 \pm 1.22$ & $58.0 \pm 1.22$ \\
T5 & $93.0 \pm 1.22$ & $84.0 \pm 1.87$ & $70.0 \pm 1.58$ \\
T6 & $96.0 \pm 1.87$ & $95.0 \pm 1.58$ & $93.0 \pm 1.22$ & $75.0 \pm 1.58$ \\
T7 & $45.0 \pm 2.24$ & $41.0 \pm 1.0$ & $36.0 \pm 1.0$ & $26.0 \pm 1.0$ \\
T8 & $90.0 \pm 1.58$ & $90.0 \pm 2.24$ & $79.0 \pm 1.87$ & $45.0 \pm 2.73$ \\
T9 & 100 & $94.0 \pm 1.0$ & $78.0 \pm 1.22$ & $57.0 \pm 1.22$ \\
T10 & 100 & $97.0 \pm 1.22$ & $89.0 \pm 1.87$ & $67.0 \pm 1.22$ \\
T11 & 100 & 100 & $96.0 \pm 1.87$ & $76.0 \pm 1.87$ \\
& 100 & 100 & 100 & $82.0 \pm 1.26$
\end{tabular}




\begin{tabular}{ccccc} 
T12 & $59.0 \pm 1.87$ & $52.0 \pm 1.22$ & $49.0 \pm 1.87$ & $33.0 \pm 1.22$ \\
T13 & 100 & $94.0 \pm 1.0$ & $87.0 \pm 1.22$ & $52.0 \pm 1.22$ \\
T14 & 100 & $99.0 \pm 1.0$ & $91.0 \pm 1.87$ & $65.0 \pm 1.58$ \\
T15 & 100 & 100 & $95.0 \pm 1.22$ & $72.0 \pm 1.22$ \\
T16 & 100 & 100 & $98.0 \pm 2.0$ & $82.0 \pm 1.22$ \\
T17 & 100 & 100 & 100 & $90.0 \pm 1.58$ \\
T18 & $68.0 \pm 1.87$ & $60.0 \pm 1.58$ & $58.0 \pm 2.0$ & $45.0 \pm 1.58$ \\
T19 & 100 & $98.0 \pm 1.22$ & $93.0 \pm 1.22$ & $64.0 \pm 1.0$ \\
T20 & 100 & 100 & $95.0 \pm 2.23$ & $72.0 \pm 1.22$ \\
T21 & 100 & 100 & 100 & $80.0 \pm 1.58$ \\
T22 & 100 & 100 & 100 & $92.0 \pm 1.22$ \\
T23 & 100 & 100 & 100 & $96.0 \pm 1.87$ \\
T24 & $73 \pm 1.22$ & $68.0 \pm 1.22$ & $60.0 \pm 1.58$ & $52.0 \pm 1.22$ \\
Control & 0 & 0 & 0 & 0 \\
\hline
\end{tabular}

** Treatment details are given in above Table 1

\section{DISCUSSION}

The effectiveness of neem plant extracts against different insect pests was reported by Kunbhar et al. ${ }^{[25]}$. Neem having rapid degradation in the environment and minimal effects of biological control agents, which make neem as excellent tree ${ }^{[26]}$. In the present study, the increase in mortality was recorded with an increase the dosage of neem oil. Similarly, Mordue (Luntz) and Blackwell ${ }^{[27]}$ also reported the increase in mortality related to increased the neem oil concentrations by to the effects of azadirachtin depend on both dose and exposure time. Jarvis et al. ${ }^{[28]}$ and Simmonds et al. ${ }^{[29]}$ also reported the insecticidal effect of neem on $S$. frugiperda, S. littoralis and Helicoverpa armigera. Viana and Prates ${ }^{[30]}$ also reported the toxic effect of aqueous neem leaf extractagainst $S$. frugiperda caterpillars, which causedthe mortality of $S$. frugiperda caterpillars. Isman et al. ${ }^{[31]}$ also reported that Azadirachta indica control $S$. frugiperda, H.virescens, S.litura and Plutella xylostella. Maredia et al. ${ }^{[32]}$ also reported the potential effect of $A$. indica against Heliocoverpa zea, S. frugiperda, Diatraea saccharalis, D. grandiosella, Sitophilus zeamais and Prostephanus truncatus. Similarly, Tavares et al. ${ }^{[1]}$ also reported the mortality of 4 or 6 days old S. frugiperda caterpillars to using neem oil.
Roel et al. ${ }^{[33]}$ recorded $100 \%$ mortality at $4,000 \mathrm{ppm}$ on immature stage of $S$. frugiperda by $A$. indica oil. Similarly, Lima et al. ${ }^{[34]}$; de Campos and Boica-Junior ${ }^{[35]}$ reported $83 \%$ mortality of FAW larvae by using neem oil. Silva et al. ${ }^{[17]}$ reported the toxic effect of aqueous neem leaf extracts against $S$. frugiperda. Duarte et al. ${ }^{[36]}$ reported effectiveness of neem oil against larva and adult of the $S$. frugiperda by the decreased the fecundity and longevity. Similarly, Sisay et al. [37] also reported the high percentage larval mortality (>95\%) in $72 \mathrm{~h}$ after exposure of $A$. indica, Schinnus molle, and Phytolacca dodecandra. When neem oil used along with wetting agent increased the mortality rate in less time. Butler and Henneberry ${ }^{[38]}$ used oils with surfactants or other adjuvants as emulsifiers which leads to increase spreading and reported very effective against whiteflies and other pests. Even Schonherr et al. ${ }^{[39]}$ also reported that when any agrochemical used along with wetting agent or surfactant leads to softening of crystalline waxes in cuticle and thus increased the mobility of the agrochemicals across the skin which leads to fast mortality.

\section{CONCLUSIONS}

The present laboratory studies revealed that the combination of neem oil (WA391: Nim Q) along with 
wetting agent (WA306: SuperStiker) are very effective in controlling the population of 2, 4, 6 and 12 days old larvae of FAW under laboratory condition. At $2 \mathrm{ml} \mathrm{Nim} \mathrm{Q}$ and $5 \mathrm{ml}$ of SuperStiker was showing maximum mortality for all selected larval stages after 24 hours. Therefore, current study motivates to use neem oil in combination of wetting agent against fall army worm under field condition.

This kind of study will decrease the indigenous use of pesticides and its adverse effects on environments and non-target living organism. Its can open the channel to use ecofriendly control measure by integrating it in integrated pest management (IPM) practices.

\section{CONTRIBUTION OF AUTHORS}

Research concept- Dr. Anita Singh

Research design- Dr. Anita Singh

Supervision- Dr. Rajas Warke, Dr. Kavita Khadke

Materials- Ms. Pallavi Waykole

Data collection- Dr. Anita Singh

Data analysis and Interpretation- Dr. Anita Singh

Literature search- Dr. Anita Singh

Writing article- Dr. Anita Singh

Critical review- Dr. Anita Singh

Article editing- Dr. Anita Singh

Final approval- Dr. Rajas Warke, Dr. Kavita Khadke

\section{REFERENCES}

[1] Tavares WS, Costa MA, Cruz I, Silveira RD, Serrao JE, Zanuncio JC. Selective effects of natural and synthetic insecticides on mortality of Spodoptera frugiperda (Lepidoptera: Noctuidae) and its predators Eriopis connexa (Coleoptera: Coccinelli dae). J. Environ. Sci. Health, 2010; 45: 557-61.

[2] Dalvi LP, Andrade GS, Pratissoli D, Polanczyk RA, Melo RL. Compatibility of biological agents to control Spodoptera frugiperda (Lepidoptera: Noctuidae). Agrarian Magazine, 2011; 4: 79-83.

[3] Goergen G, Lava KP, Sankung SB, Togola A, Tamò M. First Report of Outbreaks of the Fall Armyworm, Spodoptera frugiperda (J E Smith) (Lepidoptera, Noctuidae): A New Alien Invasive Pest in West and Central Africa. PLoS ONE, 2016; 11, e0165632.

[4] Sangomla A, Kukreti I, et. al. Rise of fall army worm. Down to Earth. Cover story-FAW 1. Indd., 2019; pp. 24-36.

[5] Sharanabasappa CM, Kalleshwaraswamy R, Asokan HM, Mahadeva Swamy MS, Maruthi HB, et al. First report of fall armyworm, Spodoptera frugiperda (J E Smith) (Lepidoptera: Noctuidae), an alien invasive pest on maize in India. Pest management in Horticulture. Ecosyst., 2018; 24 (1): 23-29.

[6] Ganiger PC, Yeshwanth HM, Muralimohan K, Vinay $\mathrm{N}$, Kumar ARV, Chandrashekara K. Occurrence of the new invasive pest, fall armyworm, Spodoptera frugiperda (J. E. Smith) (Lepidoptera: Noctuidae) in the maize fields of Karnataka, India. Current Sci., 2018; 115(4): 621-23.

[7] Srikanth J, Geetha N, Singaravelu B, Ramasubramanian T, Mahesh $\mathrm{P}$, et al. First report of occurrence of fall armyworm Spodoptera frugiperda in sugarcane from Tamil Nadu, India. J. Sugarcane Res., 2018; 8(2): 195-202.

[8] Sisodiya DB, Raghunandan BL, Bhatt NA, Verma, HS, Shewale $C P$, et al. The fall armyworm, Spodoptera frugiperda (J.E. Smith) (Lepidoptera: Noctuidae); first report of new invasive pest in maize fields of Gujarat, India. J. Entomol. Zool. Stud., 2018; 6(5): 2089-91

[9] Chormule A, Shejawal $N$, basappa $S$, Kalleshwaraswamy R, Asokan R, et al. First report of fall armyworm Spodoptera frugiperda (J.E. Smith) (Lepidoptera: Noctuidae) on sugarcane and other crops from Maharashtra, India J. Entomol. Zool. Stud., 2019; 7(1): 114-17.

[10]Yu SJ. Insecticide resistance in the fall armyworm, Spodoptera frugiperda (J. E. Smith). Pesticide Biochem. Physiol,. 1991; 39: 84-91.

[11]Mossini SAG, Kemmelmeier C. A arvore Nim (Azadirachta indica A. Juss): multiple uses. Buenos Aires pharmaceutical act, 2005; 24: 139-48.

[12] Sujarwo W, Keim AP, Caneva G, Toniolo C, Nicoletti M. Ethnobotanical uses of neem (Azadirachta indica A. Juss.; Meliaceae) leaves in Bali (Indonesia) and the Indian subcontinent in relation with historical background and phytochemical properties. J. Ethnopharmacol., 2016; 189: 186-93.

[13]Ramachandran S, Singh SK, Larroche C, Soccol CR, Pandey A. Oil cakes and their biotechnological applications-A review. Bioresource Technol., 2007; 98: 2000-09.

[14] Lokanadhan S, Muthukrishnan P, Jeyaraman S. Neem products and their agricultural applications. J. Biopesticides, 2012; 5: 72-76.

[15]Alves AP, Correa AD, Alves DS, Saczk AA, Lino JBB, Carvalho GA. Toxicity of the phenolic extract from 
jabuticabeira (Myrciariacauliflora (Mart.) O.Berg) fruit skins on Spodoptera frugiperda. Chilean J. Agricul. Res., 2014; 74: 200-04.

[16]Martinez AM, Aguado-Pedraza AJ, Vinuela E, Rodríguez- Enríquez $\mathrm{CL}$, Lobit $\mathrm{P}$, et al. Effects of ethanolic extracts of Argemone ochroleuca (Papaveraceae) on the food consumption and development of Spodoptera frugiperda (Lepidoptera: Noctuidae). Fla. Entomol., 2017; 100: 339-45.

[17]Silva MS, Broglio SMF, Trindade RCP, Ferrreira ES, Ismael BG, et al. Toxicity and application of neem in fall armyworm. Comunicata Scientiae, 2015; 6(3): 359-364.

[18]Norten E, Pütz J. Neem: India's Miraculous Healing Plant. Rochester, VT: Inner Traditions/Bear \& Co., 1999.

[19]Nicoletti M, Petitto V, Gallo FR, Multari G, Federici E, et al. The modern analytical determination of botanicals and similar novel natural products by the HPTLC fingerprint approach. Stud. Natural Products Chem., 2012; 37: 217-58.

[20]Brahmachari G. Neem an omnipotent plant: retrospection. Chem. Bio. Chem., 2004; 5: 408-21.

[21]Boeke SJ, Boersma MG, Alink GM, Van loon JJ, Vanhuis A, et al. Safety evaluation of neem (Azadirachta indica) derived pesticides. J. Ethnopharmacol., 2004; 94: 25-41.

[22]Ogbuewu IP, Odoemenam VU, Obikaonu HO, Opara $\mathrm{MN}$, Emenalom OO, et al. The growing importance of neem (Azadirachta indica A. Juss) in agriculture, industry, medicine and environment: a review. Res. J. Med. Plant, 2011; 5: 230-45.

[23]Pimentel D. Amounts of pesticides reaching the target pests: environmental impacts and ethics. J. Agricul. Environ. Ethics, 1995; 8: 17-29.

[24]Abbott WS. A method of computing the effectiveness of an insecticide. J. Economic Entomol., 1925; 18: 265-67.

[25]Kunbhar S, Rajput LB, Gilal AA, Channa GA, Sahito JGM. Impact of botanical pesticides against sucking insect pests and their insect predators in Brinjal crop. J. Entomol. Zool. Stud., 2018; 6(2): 83-87.

[26]Mordue AJL, Nisbet AJ. Azadirachtin from the neem tree Azadirachta indica: Its action against insects. Anais da Entomol. Soc. Brazil, 2000; 29: 615-32.

[27]Mordue (Luntz) AJ, Blackwell A. Azadirachtin: An update. J. Insect Physiol., 1993; 39: 903-24.
[28]Jarvis AP, Johnson SJ, Morgan ED, Simmonds MJ, Blaney WM. Photooxidation of nimbin and salannin, tetranortriterpenoids from the neem tree (Azadirachta indica). J. Chemical Ecol., 1997; 23: 2841-60.

[29]Simmonds MS, Jarvis AP, Johnson $S$, Jones $G R$, Morgan ED. Comparison of antifeedant and insecticidal activity of nimbin and salannin photooxidation products with neem (Azadirachta indica) limonoids. Pest Manag. Sci., 2004; 60:459-64.

[30]Viana PA, Prates HT. Development and larval mortality of Spodoptera frugiperda in corn leaves treated with aqueous extract of Azadirachta indica leaves. Bragantia, 2003; 62: 69-74.

[31] Isman MB. Botanical insecticides, deterrents, and repellents in modern agriculture and an increasingly regulated world. Annual Rev. Entomol., 2006; 51: 4566.

[32] Maredia KM, Segura OL, Mihm J. A Effects of Neem, Azadirachta indica on six species of Maize insect pests. Tropical Pest Manag., 1992; 38(2): 190-95.

[33]Roel AR, Dourado DM, Matias R, Porto KRA, Bednaski $A V$, et al. The effect of sub-lethal doses of Azadirachta indica (Meliaceae) oil on the mid-gut of Spodoptera frugiperda (Lepidoptera, Noctuidae). Revista Brasileira de Entomol., 2010; 54: 505-10.

[34] Lima MPL, Oliveira JV, Gondim-Junior MGC, Marques EJ, et al. Bioactivity of formulations of NIM ( Azadirachta indica A. Juss, 1797) and Bacillus thuringiensis subsp. aizawai in caterpillars of Spodoptera frugiperda (JE Smith) (Lepidoptera: Noctuidae). Sci. Agrotechnol., 2010; 34: 1381-89.

[35]de Campos AP, Boica-Junior AL. Lagartas de Spodoptera frugiperda (J. E. Smith) (Lepidoptera: Noctuidae) submetidas a diferentes nim oil concentracoes Brasileira de Milho e Sorgo Magazine, 2012; 11: 137-44.

[36]Duarte JP, Redaelli LR, Jahnke SM, Trapp S. Effect of Azadirachta indica (Sapindales: Meliaceae) Oil on Spodoptera frugiperda (Lepidoptera: Noctuidae) Larvae and Adults. Florida Entomol., 2019; 102 (2): 408-12.

[37]Sisay B, Tefera T, Wakgari M, Ayalew G, Mmendesil E. The Efficacy of Selected Synthetic Insecticides and Botanicals against Fall Armyworm, Spodoptera frugiperda in Maize. Insects, 2019; 10, 45: 1-14. 
[38]Butler GD, Henneberry TJ. Pest control on vegetables and cotton with household cooking oils and liquid detergents. Southwestern Entomol., 1990; 15: 123-31.
[39]Schonherr J, Baur P, Uhlig B. A Rates of cuticular penetration of 1-naphthylacetic acid (NAA) as affected by adjuvants, temperature, humidity and water quality. Plant Growth Regul., 2000; 31: 61-74. 